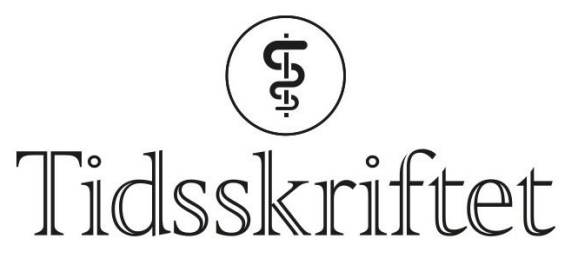

DEN NORSKE LEGEFORENING

\title{
Legen som ikke ville gjenopplives
}

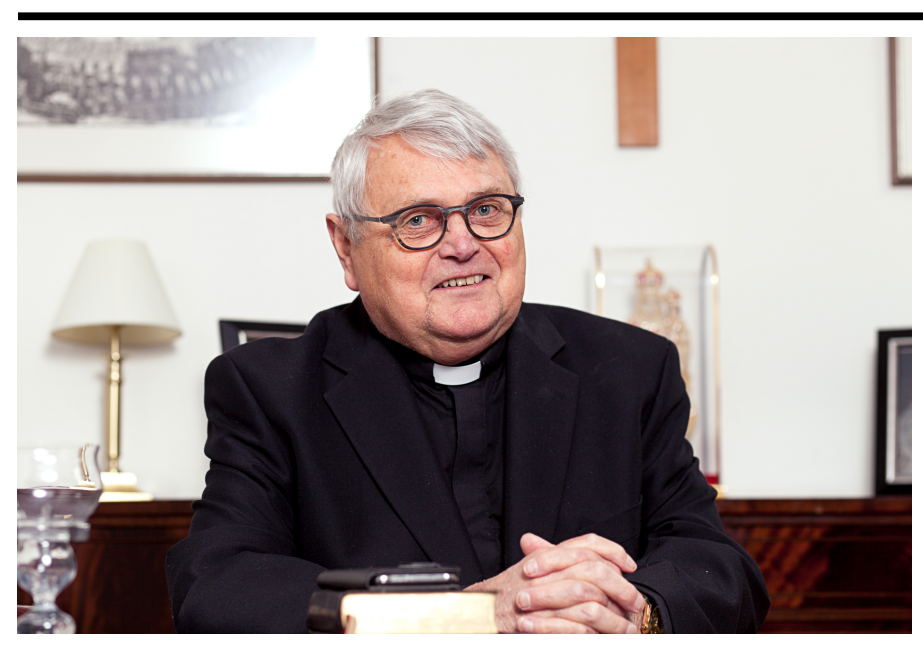

INTERVJU

\section{CHARLOTTE LUNDE}

E-post: charlottelunde@me.com

Da gynekolog Lars Jul Hansen falt om under frokosten, hadde han egentlig gitt beskjed om at han ikke ville resusciteres. Noen mener at han ble reddet av sin sideutdanning som katolsk diakon.

- Du må ha et avklart forhold til egen død når du jobber med alvorlig syke pasienter, sier Jul Hansen.

Vi møter den pensjonerte avdelingsoverlegen ved Arendal sykehus på menighetskontoret til St. Olavs kirke i Oslo sentrum. Han forteller nøkternt om morgenen i 2012 da hans eget hjerte stoppet.

- Min yngste datter Sigrid hadde vært ferdig sykepleier en måned og hadde nylig hatt praksis ved en hjertemedisinsk avdeling. Hun satte umiddelbart i gang med hjerte-lungeredning, og min kone Jorån var heldigvis også hjemme. De jobbet sammen til ambulansen kom, men på et tidspunkt utbrøt Sigrid til min kone: «Men far har jo sagt at han ikke vil resusciteres!» Da svarte Jorån: «Ti still, og jobb videre!», gjengir Jul Hansen.

Han ler en liten latter og kommenterer tørt:

- Så ble det fire-fem uker på respirator.

\section{Livets store spørsmål}

Det er vel de eneste ukene i Jul Hansens liv der han ikke har hatt anledning til å gruble over livets store spørsmål. Noe han har gjort til gagns gjennom en bred akademisk karriere både 
innenfor språk, filosofi og teologi - før medisinen tok ham. Morgenen han selv ankom sitt eget arbeidssted i ambulanse, sto kolleger klare, og ved PCI-senteret i Arendal ble det raskt lagt inn tre stenter.

\section{Lars Jul Hansen}

- Cand.mag. (filosofi grunnfag, religionshistorie mellomfag og kinesisk mellomfag) 1971

- Vitenskapelig assistent for filosof Arne Næss, slutten av 196o-årene

- Medisinstudier i Oslo 1972-78

- Turnustjeneste i Arendal og Bygland 1978-80

- Lege på Rygge flystasjon 1980-81

- Gynekologisk avdeling, Arendal sykehus 1981-83

- Gynekologisk avdeling, Akershus universitetssykehus 1983-84

- Kompetansesenter for pallativ medisin, Ullevål sykehus 1984-87

- Gynekologisk avdeling, IVF Rikshospitalet 1987

- Gynekologisk avdeling, IVF Troms $ø$ 1989-9o

- Gynekologisk avdeling, Ullevål sykehus 1990-91

- Gynekologisk avdeling, Arendal sykehus 1991-92

- Gynekologisk avdeling, Radiumhospitalet 1992-2010

- Gynekologisk avdeling, Arendal sykehus 2010-15

- Teologistudier ved Menighetsfakultetet fra 2007

- Vigslet til diakon i Den katolske kirke 2012

- Utenfor satt vår katolske sogneprest sammen med familien og ba for meg. Det var vel ikke så mange av intensivlegene på sykehuset som trodde jeg kom til å overleve, forteller den pensjonerte legen, som også selv er ordinert diakon i den katolske kirken. Noen fascinerende dødsopplevelse kan han ikke si at han hadde.

- Alt var jo svart inntil jeg våknet. Jeg fikk dessuten alle slags komplikasjoner, både i nyrer og lever, i tillegg til en lungebetennelse. Min kone var også veldig i tvil. Hun lurte jo på hvordan jeg kom til å være oppe i toppen etter noe sånt, forteller han.

- Det satte meg dessverre litt tilbake, kommenterer han lakonisk.

Det satte ham likevel ikke lenger tilbake enn at han etter bare tre måneder var tilbake på jobb som avdelingsoverlege ved gynekologisk avdeling i Arendal. Kollegene på sykehuset snakket om at Jul Hansens hadde så store mentale reserver å ta av at han ville klare seg, andre mente at forbindelsen til Gud må ha vært avgjørende.

- De fleste leter etter en mening. Den katolske tro satte alt på plass for meg, sier han i dag.

Interessen for livets store spørsmål har gitt den 72 år gamle gynekologen en uvanlig karriere. Den startet ved Oslo katedralskole, gikk deretter via kinesisk grammatikk, før veien fortsatte som vitenskapelig assistent hos filosof Arne Næss og derfra videre til onkogynekologi før han etter hvert ble diakonvigslet i 2012.

- En av mine gode venner på gymnaset hadde en mor som var katolikk og skuespiller, og der hjemme hadde jeg også gleden av å treffe pater Hallvard Rieber-Mohn. Han ga meg god hjelp i konverteringsprosessen, forteller Jul Hansen. Mannen bak sitatet: «Det er ingen 
grunn til å gruble så meget over livet, man slipper likevel ikke levende fra det», Fredrik Stabel, var også blant omgangsvennene i dette hjemmet. Jul Hansen husker morsomme samtaler rundt bordet hjemme hos klassekameraten.

- Jeg har aldri ledd så mye i hele mitt liv.

\section{Brakk ribben}

Med en oppvekst hos radikale akademikerforeldre i Kristiansand var det ikke forventet at Jul Hansen skulle bli verken lege eller katolikk.

- Min far var lege, men ville egentlig bli arkitekt, og min bestefar var kommunist og ateist, mens min mor tilhørte Dagblad-Venstre, forteller Jul Hansen og illustrerer foreldrenes uhøytidelige forhold til kirkelige ritualer:

- Da jeg ble døpt, var far hjemme og laget lapskaus til selskapet, mens mor bar meg til døpefonten.

Som diakon har han nå selv anledning til både å vie, forrette og døpe, og nylig hadde han også gleden av å døpe sitt eget barnebarn. Familien har vært uvurderlig. En novemberdag i 2015 var det hans eldste datter som kom ham til unnsetning. Denne søndagen sto han ved alteret og leste evangeliet da han plutselig besvimte.

- Min eldste datter er også lege. Hun trodde jeg hadde fått en ny stans og startet raskt resuscitering. Hun endte med å knekke to ribben på meg.

Lars Jul Hansen smiler, men dveler ikke ved historien. Han går raskt videre i sin omtale av familien.

- Og så har vi en sønn. Ham snakker vi ikke om. Han er familiens sorte får, sier Jul Hansen. Etter en kunstpause legger han til:

- Han er økonom.

\section{«Teach yourself chinese»}

Selv hadde han tidlig en plan om å bli lege, men der andre kanskje tar et friår før man starter å studere, valgte Lars Jul Hansen «å gjøre noe morsomt».

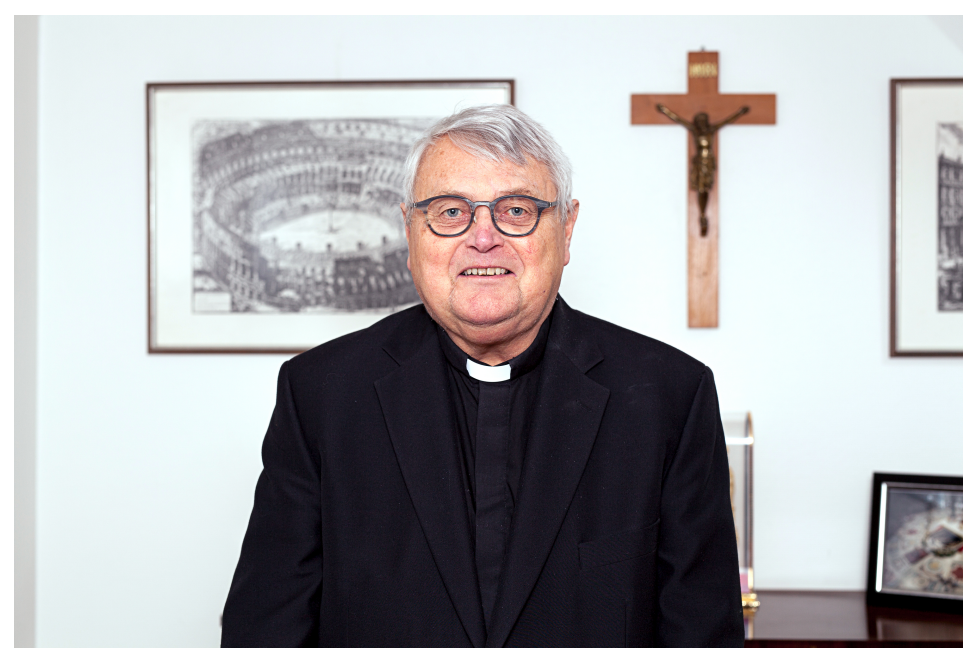

- Jeg ble etter hvert ganske lei naturfag utover i gymnastiden. Det var likevel helt tilfeldig at jeg begynte å lese filosofi - særlig middelalderfilosofi - og så var det like tilfeldig at jeg kom forbi en kinesisk kunstutstilling ved siden av Chat Noir, like ved Katta. Jeg ble så fascinert av de kinesiske tegnene at jeg gikk sporenstreks til Norli og kjøpte Teach yourself chinese. Der og da bestemte jeg meg for å gjøre noe morsomt først, før jeg skulle bli lege, forteller Jul Hansen.

«Noe morsomt» betød studier i kinesisk på et nivå som førte til utgivelsen av det han kaller sitt ungdomsverk: En håndbok i kinesisk språkstruktur. 
- Den kom første gang ut i 1977. Opplaget tok slutt i 1990-årene, men det morsomme er at boken fremdeles brukes blant studenter på Blindern som studerer kinesisk. Den finnes også i en piratutgave trykket på taiwansk, så den fikk faktisk en viss utbredelse, forteller forfatteren.

Skriveprosessen, forteller kilder, foregikk i baksetet på en gusjegul folkevognboble der Jul Hansen hadde en stor skrivemaskin tilgjengelig. Filosofistudiene foregikk også til dels i ulendt terreng. I en forblåst, men ganske så berømt hytte oppunder Hallingskarvet, ble han med Arne Næss på studietur. På Tvergastein, den selvbygde hytta til Næss, «der taket ble holdt på plass av barduner så ikke det skulle blåse bort», ble Jul Hansen med Næss for å skrive artikler om middelalderfilosofen Spinoza.

- Vi satt inne i et lite hulrom hvor vi både spiste, diskuterte, sov og arbeidet. Næss var et utrolig inspirerende menneske. Det gikk jo rundt og rundt oppi hodet absolutt hele tiden, og han hadde all verdens merkelige påfunn. Han klatret jo ikke bare i fjellet, men også utenpå et av byggene på Blindern en gang, husker jeg.

- Ble hans vitenskapelige assistent med på det?

- Nei, tusen takk!

\section{Et kall}

Etter perioden som vitenskapelig assistent for Arne Næss reiste Jul Hansen videre til Nederland.

- Jeg fikk et nederlandsk statsstipend og dro til Leiden for å fortsette med kinesisk med tanke på et hovedfag. Men der nede fant jeg egentlig fort ut at hvis jeg skulle bli ekspert $\mathrm{i}$ kinesisk, ville det bli et liv på Blindern, eventuelt innenfor journalistikk eller diplomati, sier Jul Hansen og antyder at det fristet ikke.

Etter åtte måneder i Leiden reiste han tilbake til Norge og begynte på medisinstudiet.

- Det som jeg er opptatt av, begynner Jul Hansen og kremter.

- Jeg vet ikke hvor høytidelig jeg skal bli, men da jeg var i Nederland og skulle studere kinesisk, hadde jeg en slags visjon eller et slags kall som gjorde at jeg bestemte meg for at jeg måtte bli lege. Jeg tror at en lege bør ha en relativt bred bakgrunn i sin legegjerning. Kommunikasjon er så viktig, summerer Jul Hansen.

- Det var jo i noen år slik at medisinstudentene ble rekruttert fra andre fag, at de hadde et grunnfag i filosofi, psykologi eller sosiologi. Man vektla at de hadde en slags plattform, sier han.

Den pensjonerte avdelingsoverlegen tror det var vanligere at medisinere var mer bredspektrede før i tiden, og han er lei for at det i en tid med økende subspesialisering ser ut til å avta.

\section{Barmhjertighet og sikre perioder}

Selv om det har vært et liv med flere parallelle karrierer har Jul Hansen likevel aldri vært i tvil. Han ville valgt legeyrket igjen. Etter 40 år som gynekolog, de fleste av dem med kreftpasienter, er det mange møter som har satt sine spor. 


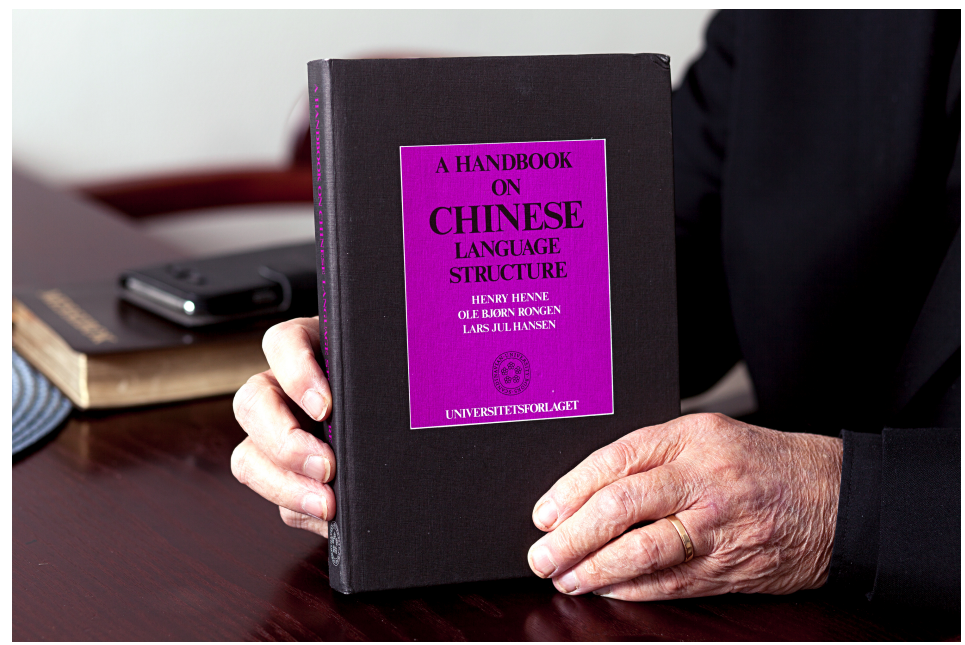

- Jeg må si at det er noen fantastiske mennesker, sier han. - Jeg savner dem veldig, og særlig alle de gode samtalene. Det synes jeg har vært veldig givende. Jeg husker så godt en ugift, ensom dame med terminal kreft. Hun var kristen og grudde seg til slutten. Hun var ikke redd for den fysiske døden, men det som kom etterpå. Vi hadde flere samtaler hvor det kom frem at hun var livredd for å dø fordi hun trodde at hun skulle straffes, husker Jul Hansen.

- Jeg har tenkt at det er noe negativt med kristendommen når den ikke klarer å formidle håpet og barmhjertigheten.

Dette bringer ham inn på sitt eget valg om å konvertere til katolisismen.

- Luther peker hele tiden på hvor syndig mennesket er. Katolisismen har et mer positivt syn på menneskene, slik jeg ser det, sier han og gir meg et eksempel på den katolske kirkens pragmatiske holdning.

- For katolikker er det en plikt å møte til høymesse hver søndag, men hvis omstendighetene gjør at man ikke kommer seg dit, kan man også gå på lørdag. Kirkeretten er vel og bra, men til syvende og sist er det din samvittighet som gjelder, forklarer Jul Hansen.

Som gynekolog og praktiserende katolikk slipper han ikke helt unna en samtale om prevensjon og abort.

- Nå er det jo slik at det er mange katolske familier med bare to barn. I 1960-årene ble det fremsatt et ønske om å liberalisere pavekirkens forhold til prevensjon. Dette ble jo ikke tatt til følge, men pavekirken anbefaler i dag bruk av sikre perioder som et alternativ, sier Jul Hansen.

Han er likevel opptatt av å understreke at den katolske kirke er mer pragmatisk enn den protestantiske. Når det gjelder reservasjonsretten for leger, har han selv benyttet seg av den, men han jobbet også flere år ved IVF-klinikken i Tromsø.

- Det var før du ble katolikk?

- Hmm, ja, du har et poeng der. Samtidig har jeg sett mange par som strever med dette. Det er en stor påkjenning for dem dette gjelder.

- Hva tenker du om det nå?

- Etter at jeg var blitt katolikk diskuterte jeg det med en prest. Han sa at det for så vidt var greit med IVF-behandling, men han var ikke sikker på om han ville anbefale meg å fortsette med det, medgir den pensjonerte gynekologen.

Han nøler litt når han blir spurt om interessekonflikten mellom pasientomsorg og katolisismens lære. Han påpeker likevel at legegjerningen går foran troen.

- Jeg har ikke noe prinsipielt imot assistert befruktning, men jeg ville ikke følt meg helt vel hvis jeg fremdeles hadde jobbet med dette til daglig, medgir han.

- Det er mange skjær i sjøen når det gjelder bioteknologi og gynekologi. Bioetikk er et vanskelig fag, konkluderer han og utdyper ikke mer. 
Hans kliniske arbeid har likevel aldri kommet i direkte konflikt med troen utover spørsmålet om abort. Tvert imot synes han den har vært til stor hjelp.

- Det har vært lettere å snakke med alvorlig syke og døende pasienter. Jeg tenker at man også må ha et avklart forhold til egen død når man jobber med kreftpasienter, sier Jul Hansen og runder av:

- Jeg er jo forberedt på at en hjertestans kan skje når som helst på nytt. Sånn er livet - det må man bare finne seg $\mathrm{i}$.

Publisert: 13. november 2017. Tidsskr Nor Legeforen. DOI: 10.4045/tidsskr.17.0835

(C) Tidsskrift for Den norske legeforening 2020. Lastet ned fra tidsskriftet.no 